\title{
Perancangan Aplikasi Pembayaran Sumbangan Pembinaan Pendidikan Pada Pondok Pesantren Terpadu Al- Istiqomah
}

\author{
$\underline{\text { Rifa Nurafifah Syabaniah }}{ }^{1}$, Andi Riyanto ${ }^{2}$, Hilma Robiatul Adawiyah ${ }^{3}$, Nuryanti $^{4}$ \\ Sistem Informasi, Fakultas Teknik dan Informatika Komputer, Universitas Bina Sarana Informatika \\ Jl. Cemerlang No. 8 Sukakarya, Kota Sukabumi, Indonesia \\ rifa.rrf@bsi.ac.id ${ }^{1}$,andi.iio@bsi.ac.id ${ }^{2}$,hilma@bsi.ac.id ${ }^{3}$,nuryanti090595@gmail.com ${ }^{4}$
}

\begin{abstract}
Payment information system for Educational Development Donations (EDD) is a monthly payment or contribution from students at school. Payment of tuition fees is taken based on the agreement of the meeting between the school and the parents of the guardians of students. PPT Al Istiqomah is an institution that is engaged in education by combining modern boarding schools and schools. At present the management of data and payment for PPT Al Istiqomah has not been well-systemized, causing problems in the processing of EDD payment transactions and recording the receipt of EDD payment reports which takes quite a long time. The results of this study was EDD payment applications that can be used by institutions / foundations for the problems faced so as to facilitate the administration process of EDD payments and minimize errors in the transaction and recording the receipt of EDD payment reports.
\end{abstract}

Keywords: Education Development Donations (EDD), Payment Information System for EDD, EDD payment applications.

\begin{abstract}
Abstrak
Sistem informasi pembayaran Sumbangan Pembinaan Pendidikan (SPP) merupakan pembayaran atau iuran setiap bulannya dari siswa di sekolah. Pembayaran SPP diambil berdasarkan kesepakatan hasil rapat antara pihak sekolah dan orang tua wali siswa. PPT Al Istiqomah merupakan lembaga yang bergerak dalam bidang pendidikan dengan memadukan pesantren modern dan sekolah. Saat ini pengelolaan data dan pembayaran SPP PPT Al Istiqomah belum tersistem dengan baik, sehingga menimbulkan masalah dalam proses transaksi pembayaran SPP dan pencatatan laporan penerimaan pembayaran SPP yang membutuhkan waktu cukup lama. Hasil dari penelitian ini adalah aplikasi pembayaran SPP yang dapat digunakan lembaga/yayasan untuk permasalahan yang dihadapi sehingga memudahkan dalam proses administrasi pembayaran SPP serta meminimalkan terjadinya kesalahan dalam transaksi dan pencatatan laporan penerimaan pembayaran SPP.
\end{abstract}

Kata Kunci: Sumbangan Pembinaan Pendidikan (SPP), Sistem Informasi Pembayaran SPP, aplikasi pembayaran SPP.

\section{Pendahuluan}

Tuntutan pemanfaatan teknologi saat ini bukan hanya domain sekolah umum, namun era sekarang pesantren juga dituntut untuk membuka diri terhadap kemajuan teknologi agar siap menghadapi era industri 4.0. Pesantren sebagai salah satu organisasi yang bergerak dalam bidang pendidikan keagamaan sudah saatnya menerapkan sistem informasi yang terintegrasi dengan internet. Pondok Pesantren Terpadu Al-Istiqomah sebagai salah satu pesantren yang bergerak dalam bidang pendidikan keagamaan terus berusaha untuk meningkatkan mutu pelayanan terhadap pengajar dan santri. Salah satunya melalui pelayanan pembayaran Sumbangan Pembinaan Pendidikan (SPP).

Salah satu sumber dana untuk membiaya operasional sekolah bersumber dari sumbangan pembinaan pendidikan (SPP), hal ini sangat penting terutama bagi sekolah swasta [1][2]. Sumbangan Pembinaan Pendidikan (SPP) merupakan iuran yang dibayarkan setiap bulan dari siswa yang menjadi kewajiban bagi siswa disekolah, pembayaran tersebut berdasarkan kesepakatan rapat komite sekolah dengan orang tua siswa untuk menunjang peningkatan mutu pendidikan diantaranya sarana dan prasarana untuk menunjang proses kegiatan belajar dan mengajar di sekolah. [3][4]

Sistem Pembayaran merupakan salah satu unsur pokok dalam upaya peningkatan mutu sumber daya manusia (SDM). Kelancaran proses sistem pembayaran merupakan hal yang harus di perhatikan terutama 
kecepatan dan ketepatan waktu agar pelayanan terhadap masyarakat khususnya wali siswa dan siswa itu sendiri dapat dilayani dengan baik. [5]

Proses pembayaran dengan sistem manual berpotensi menimbulkan kesalahan, memakan banyak waktu. penggunaan sistem yang baru diharapkan dapat mengurang kesalahan yang sering terjadi dan mengefisienkan waktu. [6]. Sistem informasi berbasis web merupakan salah satu bentuk pengintegrasian teknologi ke dalam sistem informasi. Sistem informasi sangat membantu dalam pengelolahan data penyimpanan data sehingga menghasilkan sistem informasi akurat. [7] Saat ini web menjadi gudang informasi yang sangat besar. [8]

PPT Al Istiqomah merupakan lembaga yang bergerak dalam bidang pendidikan dengan memadukan pesantren modern dan sekolah. Pada pesantren, pembayaran SPP juga dilaksanakan untuk setiap jenjang pendidikan yang mereka miliki dengan periode bulanan. [9] Saat ini pengelolaan data dan pembayaran SPP PPT Al Istiqomah belum tersistem dengan baik, sehingga menimbulkan masalah dalam proses transaksi pembayaran SPP dan pencatatan laporan penerimaan pembayaran SPP yang membutuhkan waktu cukup lama karena harus membuka arsip berupa kartu pembayaran, kwitansi, buku pencatatan yang memungkinkan beresiko arsip rusak atau hilang. Sehingga dibutuhkan solusi untuk mengatasi permasalahan pengelolaan data keuangan khususnya dalam administrasi pembayaran SPP, dengan suatu sistem yang terkomputerisasi maka akan membantu lembaga meminimalkan terjadinya kesalahan dalam proses pencatatan laporan penerimaan pembayaran SPP.

Tujuan dari penelitian ini adalah membangun sebuah aplikasi penerimaan SPP berbasis web untuk mengatasi semua kendala yang dihadapi, khususnya dalam hal waktu yang dibutuhkan untuk proses transaksi pembayaran SPP dan pencatatan laporan penerimaan pembayaran SPP akan lebih efisien.

Referensi penelitian pertama menyatakan dengan adanya aplikasi pembayaran SPP dapat mempercepat dalam memberikan pelayanan informasi data bagi pihak-pihak yang membutuhkan seperti siswa, bagian keuangan dan output akhir berupa laporan kepada kepala sekolah. [10] Referensi kedua dari [11] menyimpulkan bahwa sistem informasi pembayaran SPP dengan menggunakan bahasa pemograman PHP dan MySQL sebagai tempat penyimpanan database dapat mengakomodasi kebutuhan dalam proses pembayaran keuangan siswa secara efektif dan efisien karena dapat diakses secara realtime. Referensi ketiga dari [12] menyatakan sistem informasi pembayaran SPP dapat mengelola data siswa, mengelola laporan pembayaran bulanan dan yang menunggak.

\section{Metodologi}

Metodologi penelitian bertujuan menggambarkan kegiatan yang akan dilaksanakan selama penelitian. [13] Metode penelitian yang dilakukan pada penelitian ini meliputi proses pengumpulan data dan melakukan pengembangan perangkat lunak (Software), adapun metode penelitian yang dilakukan sebagai berikut:

\subsection{Metode Pengumpulan Data}

Metode pengumpulan data dilakukan dengan cara pengamatan secara mendalam dengan mencari informasi dari sumbernya yaitu mendatangi PPT Al Istiqomah untuk mendapatkan informasi yang lebih spesifik, dilanjutkan dengan melakukan wawancara, tanya jawab secara langsung kebagian staff administrasi lembaga PPT Al Istiqomah. Selain itu dilakukan kepustakaan melalui referensi-referensi yang berkaitan dengan permasalahan tentang pembayaran SPP dan penelitian serupa yang telah dilakukan sebelumnya.

\subsection{Metode Pengembangan Perangkat Lunak}

Metode pengembangan perangkat lunak (Sofware Development Process) pada penelitian ini terdiri dari beberapa tahapan yang dilakukan diantaranya:

a. Menganalisa kebutuhan perangkat lunak dengan cara menganalisa semua kebutuhan termasuk dokumen dan tampilan (interface) yang diperlukan guna menentukan solusi perangkat lunak yang akan digunakan sebagai proses komputerisasi sistem. 
b. Membuat desain untuk mendefinisikan yang terkait dengan pengembangan aplikasi dan rancangan databes dengan menggunakan Netbeans sebagai desain perogramnya.

c. Membuat code generation dengan cara pembuatan program dengan menggunakan kode atau bahasa pemrograman, menggunakan jenis bahasa pemrograman yaitu Java Application dan PhpMyadmin.

d. Melakukan pengujian testing yang dilakukan dengan menggunakan blackbox testing untuk memastikan semua bagian telah diuji dan meminimalisir kesalahan (error).

e. Menganalisa peralatan pendukung (Support) dengan cara menganalisa upaya-upaya pengembangan terhadap sistem yang sedang dibuat dalam menghadapi, mengantisipasi perkembangan maupun perubahan sistem yang bersangkutan terkait dengan hardware dan software yang akan digunakan.

\section{Hasil dan Pembahasan}

Berdasarkan hasil pengamatan secara mendalam pada PPT Al-Istiqomah bahwa sistem pembayaran Sumbangan Penyelenggaraan Pendidikan (SPP) yang dilakukan memiliki beberapa prosedur sistem berjalan diantaranya sebagai berikut ini:

\subsection{Prosedur Pembayaran SPP}

Proses diawali dengan siswa datang ke kantor ke bagian bendahara melakukan pembayaran SPP bulanan, kemudian siswa memberikan kartu dan uang untuk pembayarannya ke bagian bendahara. Bagian bendahara memeriksa uang apakah jumlah uang yang diberikan sesuai, apabila sesuai maka bagian bendahara mencatat pembayaran SPP pada kartu SPP dan mencatatnya pada buku arsip bendahara. apabila tidak sesuai maka bagian bendahara menginformasikan ke siswa. Kemudian bagian bendahara akan menyerahkan kembali kartu pembayan SPP dan siswa menerima bukti pembayaran kepada siswa. Adapun activity diagram prosedur pembayaran SPP di gambarkan pada diagram berikut:

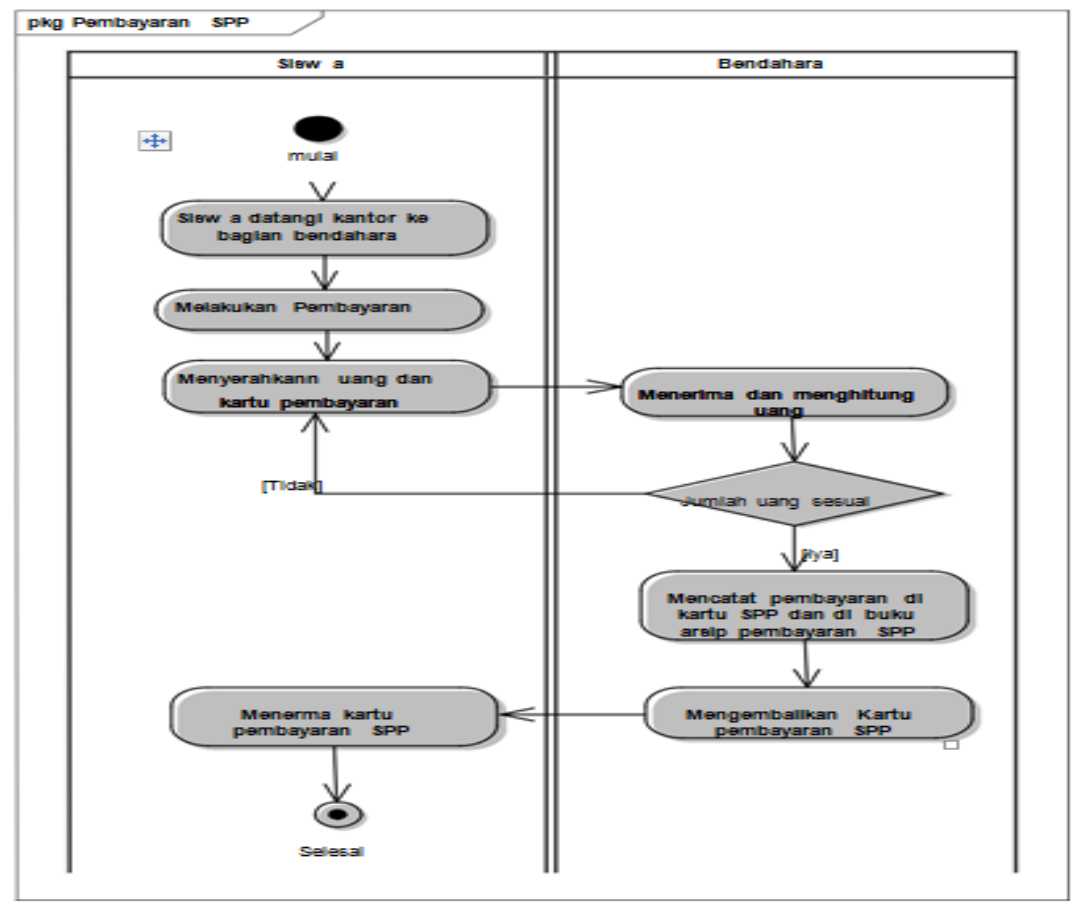

Gambar 1. Activity Diagram Prosedur Pembayaran SPP

\subsection{Prosedur Pembuatan Laporan SPP}


Setiap akhir bulan, bagian bendahara membuat laporan pembayaran SPP, kemudian bagian bendahara memberikan hasil laporan pembayaran SPP kepada ketua yayasan. Activity diagram prosedur pembuatan laporan SPP dapat dilihat pada gambar berikut:

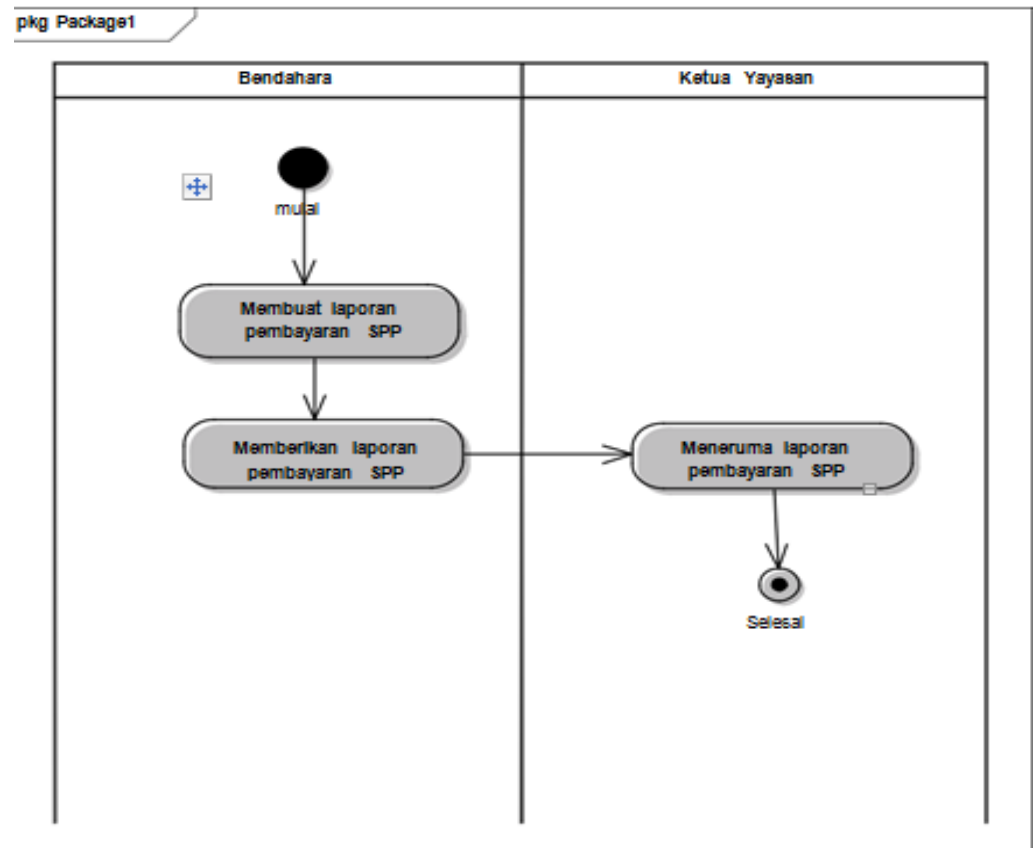

Gambar 2. Activity Diagram Prosedur Pembuatan Laporan SPP

Berdasarkan prosedur hasil pengamatan yang sedang berjalan di PPT Al-istiqomah, menunjukan bahwa pengelolaan data dan pembayaran SPP PPT Al Istiqomah belum tersistem dengan baik, sehingga menimbulkan masalah dalam proses transaksi pembayaran SPP dan pencatatan laporan penerimaan pembayaran SPP yang membutuhkan waktu cukup lama.

Solusi pemecahan masalah tersebut adalah dengan merancang aplikasi sistem pembayaran sumbangan pembinaan pendidikan (SPP) dengan fitur yang terdiri dari:

1. Sistem yang dirancang pada sistem informasi pembayaran SPP dengan fasilitas tombol pencarian sehingga pencarian data dapat di lakukan dengan mudah dan cepat.

2. Sistem juga dapat melakukan pencocokan arsip pembayaran sehingga proses pencarian tidak mengalami kesulitan dan proses pembayaran akan lebih cepat dan kinerja staf akan menjadi lebih efisien.

3. Sistem dibuat dengan rancangan secara terintegrasi sehingga laporan dapat dilihat secara otomastis sehingga meminimalisir terjadinya kesalahan dalam pembuatan laporan pembayaran SPP.

\subsection{Pemodelan Sistem}

Pemodelan sistem pada aplikasi ini menggunakan Use Case diagram, Sequence diagram, dan Deployment diagram. berikut adalah gambaran Use Case diagram untuk Aplikasi SPP Ponpes Alistiqomah;

\section{a. Use Case diagram Aplikasi SPP}

Pada gambar 3, Actor hanya satu yaitu admin, dimana admin harus melakukan login terlebih dahulu dengan memasukan username dan password yang benar, jika login sukses maka admin dapat melihat tampilan beranda, data siswa, kelas, jenis pembayaran, pembayaran SPP. serta admin dapat mengubah data akun, mengelola jurnal umum dan laporan pembayaran. Tetapi jika admin gagal melakukan login maka admin tidak bisa mengakses tampilan-tampilan yang tersedia dan akan kembali pada tampilan logout. 


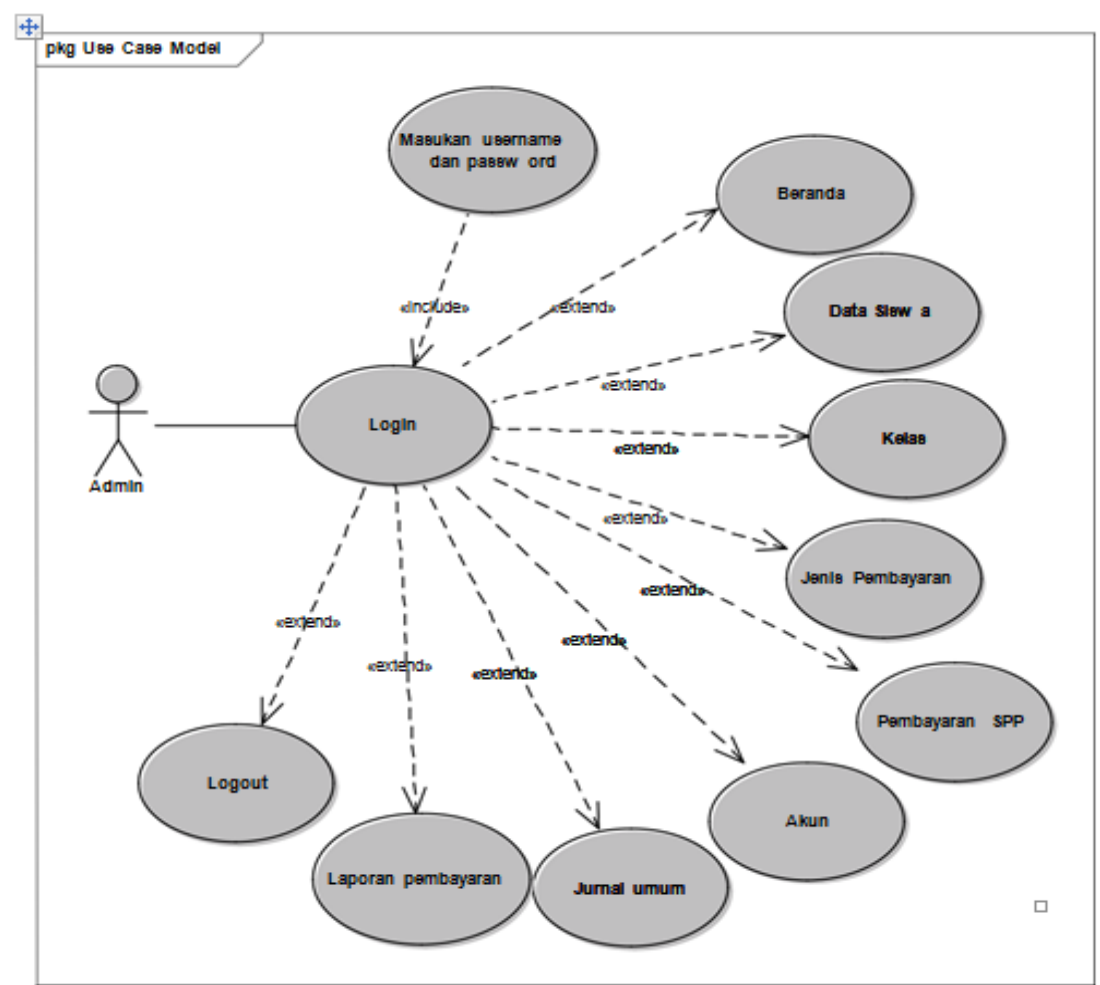

Gambar 3. Use Cse Diagram Aplikasi Sistem Pembayaran SPP Ponpes Al-Istiqomah.

b. Sequence Diagram Aplikasi SPP

Pada gambar 4, menjelaskan tentang bagaimana admin melakukan login pada sistem, admin harus input username dan password. Control login akan menyesuaikan username dan password yang di input admin, jika sesuai maka sistem tampilan akan diteruskan ke halaman utama.

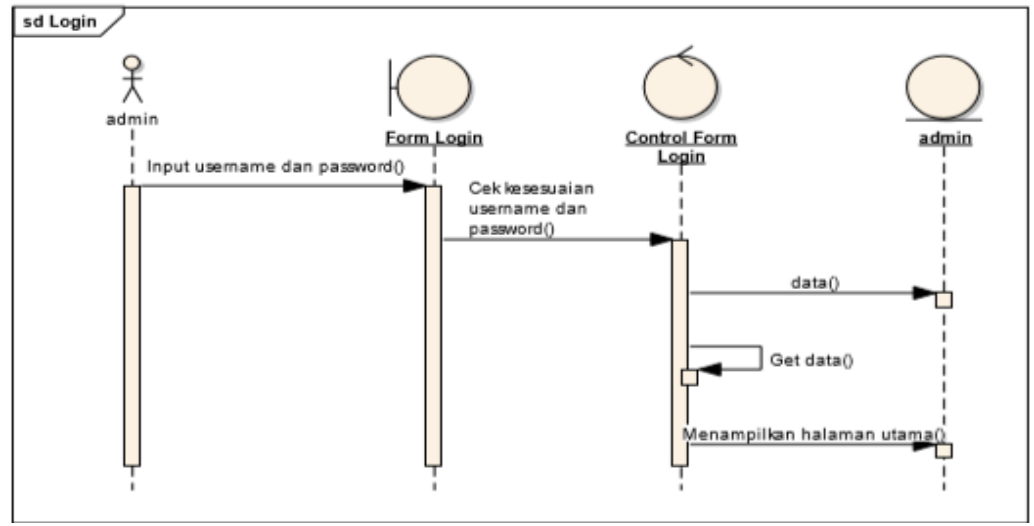

Gambar 4. Sequence Diagram Aplikasi SPP Ponpes Al-Istiqomah

Pada gambar 5, menjelaskan tentang bagaimana admin mengolah data pembayaran SPP, mulai dari form input data pembayaran, melakukan cetak pembayaran siswa, mengambil data pembayaran dan mencocokan data siswa yang melakukan pembayaran sampai proses cetak bukti pembayaran. 


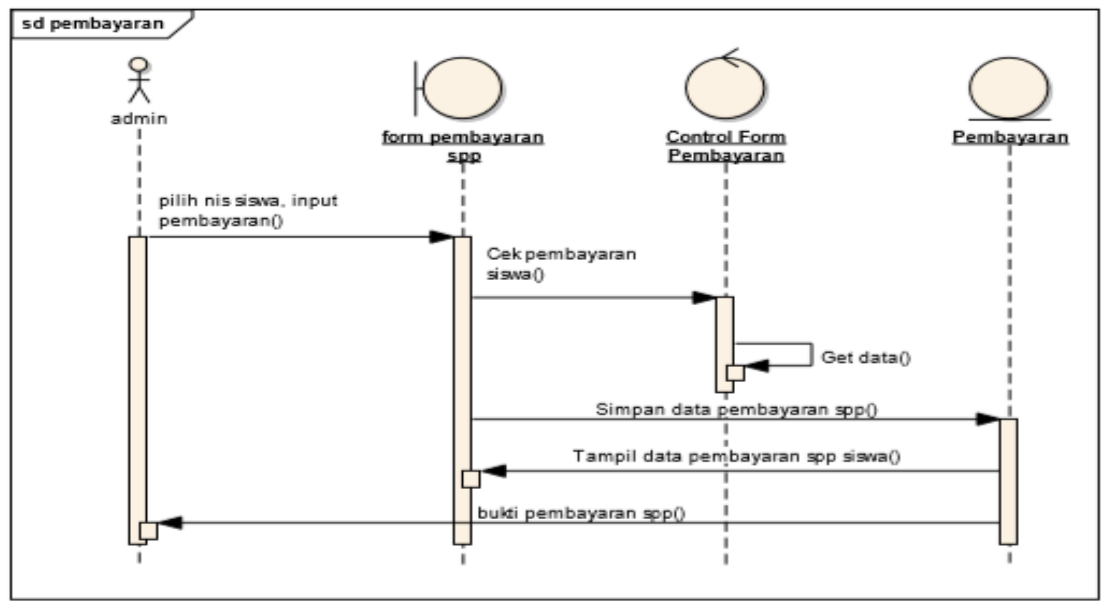

Gambar 5. Sequence Diagram Aplikasi SPP Ponpes Al-Istiqomah

c. Deployment Diagram Aplikasi SPP

Deployment diagram aplikasi SPP yang dirancang terdiri dari active control menggunakan PHP sebagai perangkat lunak editor coding bahasa pemrograman, connection menggunakan Xampp sebagai penghubung antara PHP dengan device database. Adapun database yang digunakan menggunakan perangkat lunak MySQL dengan nama database pembayaran_spp sebagai penyimpanan data, yang ditampilkan ke dalam aplikasi sistem informasi pembayaran SPP Ponpes Al-istiqomah

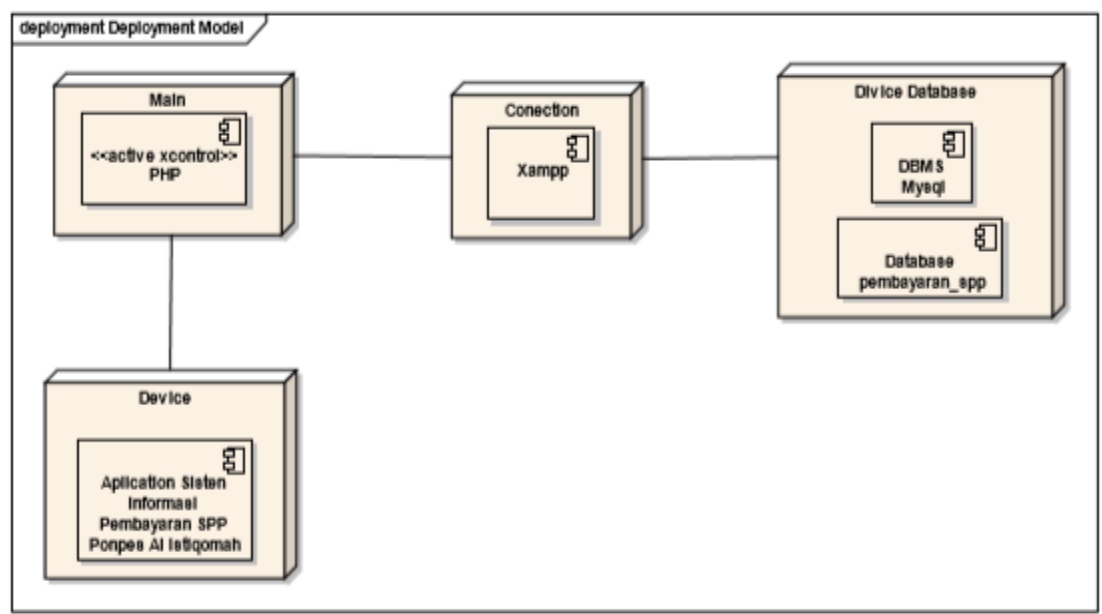

Gambar 6. Deployment Diagram Aplikasi SPP Ponpes Al-Istiqomah

\subsection{Hasil Implementasi}

Implementasi program pada penelitian ini memiliki tujuan untuk pengujian program yang sudah dibuat sehingga hasil dari program dapat diketahui apakah sudah sesuai dengan yang dinginkan dan dibutuhkan untuk memecahkan permasalahan administrasi pembayaran SPP yang terjadi pada Pondok Pesantren AlIstiqomah.

a. Halaman Login

Halaman login adalah tampilan utama aplikasi sistem pembayaran SPP Ponpes Al-istiqomah. Pada halaman ini user diarahkan untuk mengisi username dan password. 


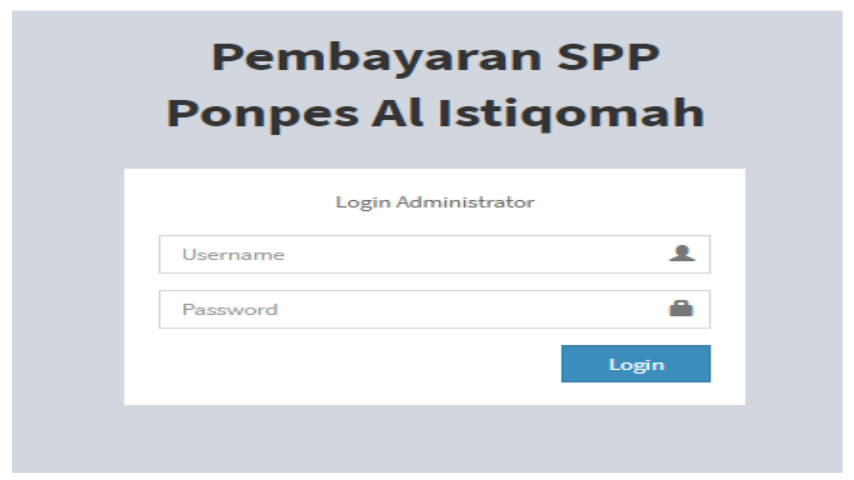

Gambar 7. Halaman Login

b. Halaman Beranda

Pada halaman beranda, user akan diarahkan ke dalam beberapa pilihan sistem pembayaran SPP diantaranya: Data Siswa, Kelas, Jenis Pembayaran, Pembayaran SPP, Akun, Jurnal Umum, Laporan Pembayaran dan Logut.

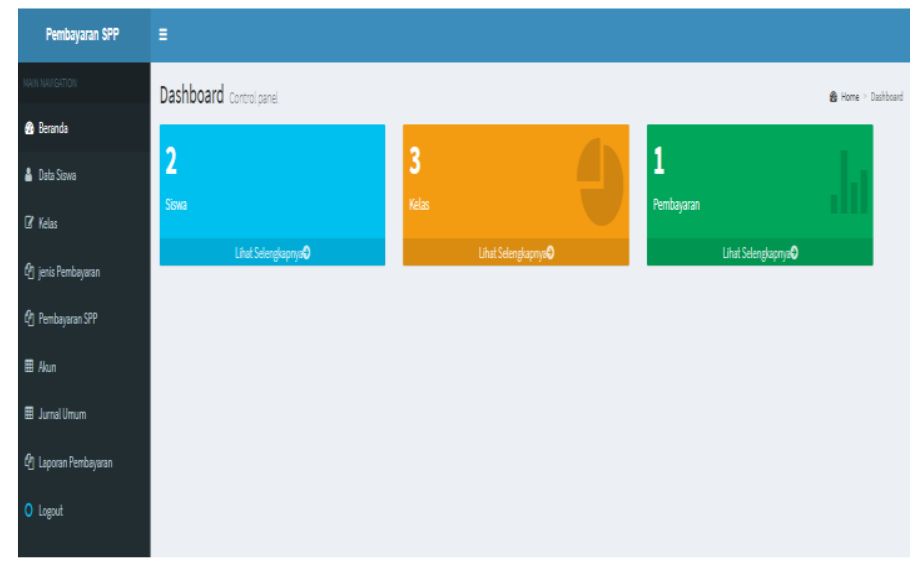

Gambar 8. Halaman Beranda

c. Halaman Data Siswa

Pada halaman data siswa berfungsi sebagai data utama untuk penyimpanan data siswa yang terdaftar sebagai siswa di Ponpes Al-Istiqomah. Fasilitas yag disediakan pada halaman ini selain menyimpan dapat juga merubah dan menghapus data siswa Ponpes Al-Istiqomah apabila sewaktu-waktu dibutuhkan.

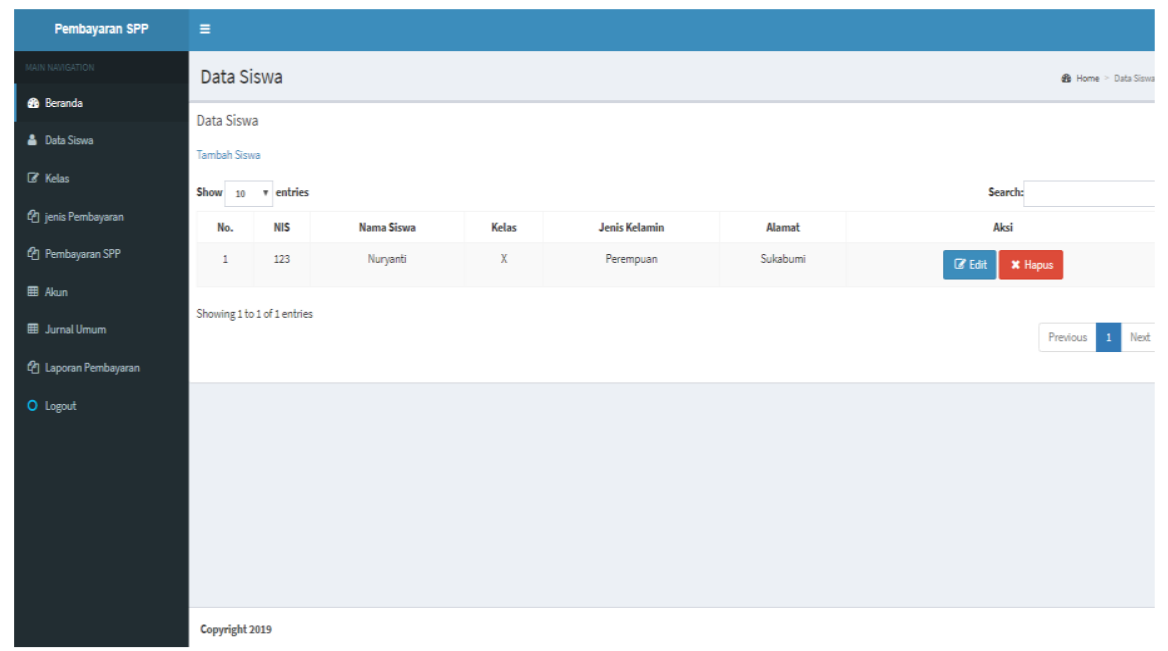

Gambar 9. Halaman Data Siswa 
d. Halaman Data Kelas

Pada halaman data kelas berfungsi sebagai data utama untuk penyimpanan data kelas yang ada di Ponpes Al-Istiqomah. Fasilitas yag disediakan pada halaman ini selain menyimpan dapat juga merubah dan menghapus data kelas Ponpes Al-Istiqomah apabila sewaktu-waktu dibutuhkan.

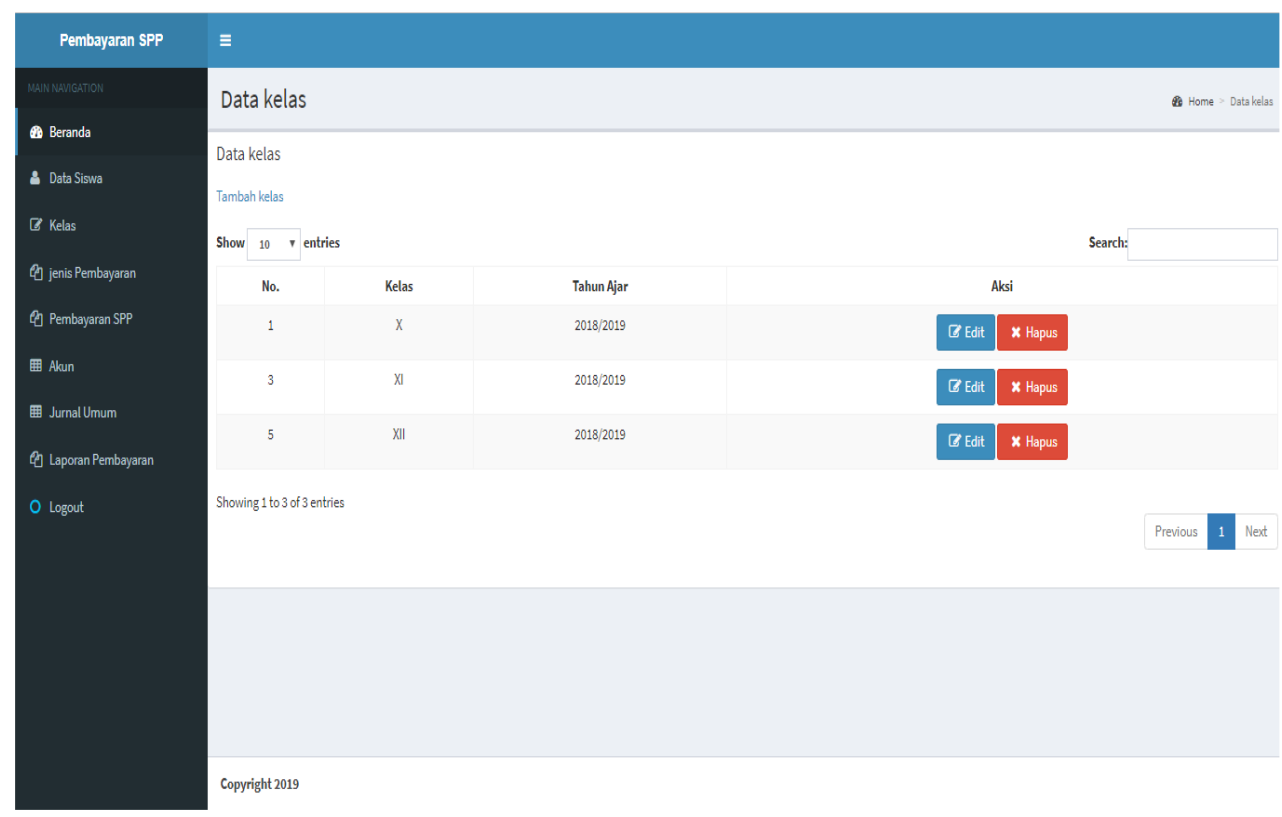

Gambar 10. Halaman Data Kelas

e. Halaman Jenis Pembayaran

Pada halaman jenis pembayaran berfungsi sebagai data transaksi untuk pemilihan jenis pembayaran di Ponpes Al-Istiqomah.

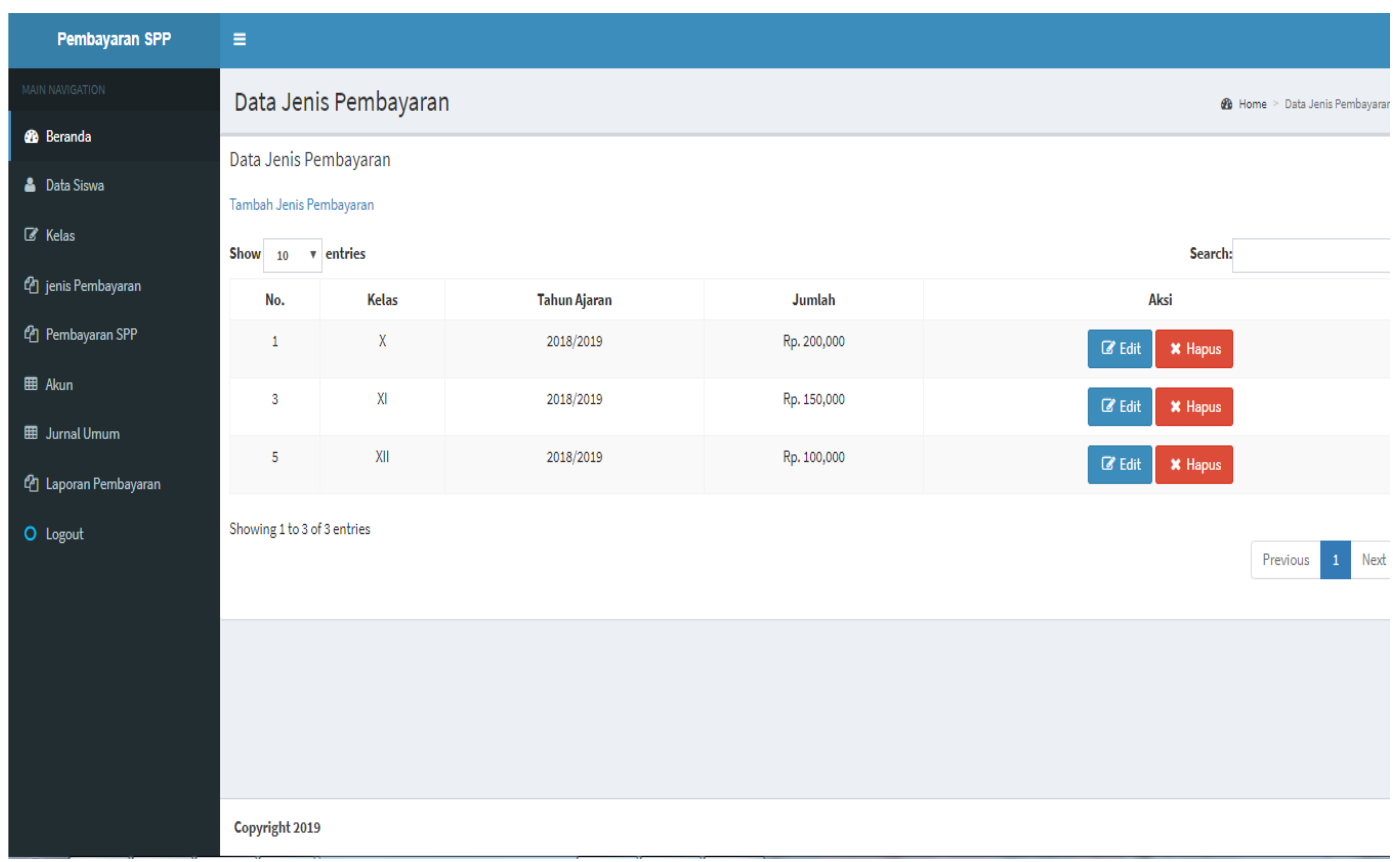

Gambar 11. Halaman Jenis Pembayaran

f. Halaman Pembayaran SPP 
Pada halaman pembayaran SPP berfungsi sebagai data transaksi untuk penyimpanan data pembayaran siswa di Ponpes Al-Istiqomah. Fasilitas yag disediakan pada halaman ini selain menyimpan dapat pembayaran juga dapat merubah dan menghapus data transaksi pembayaran.

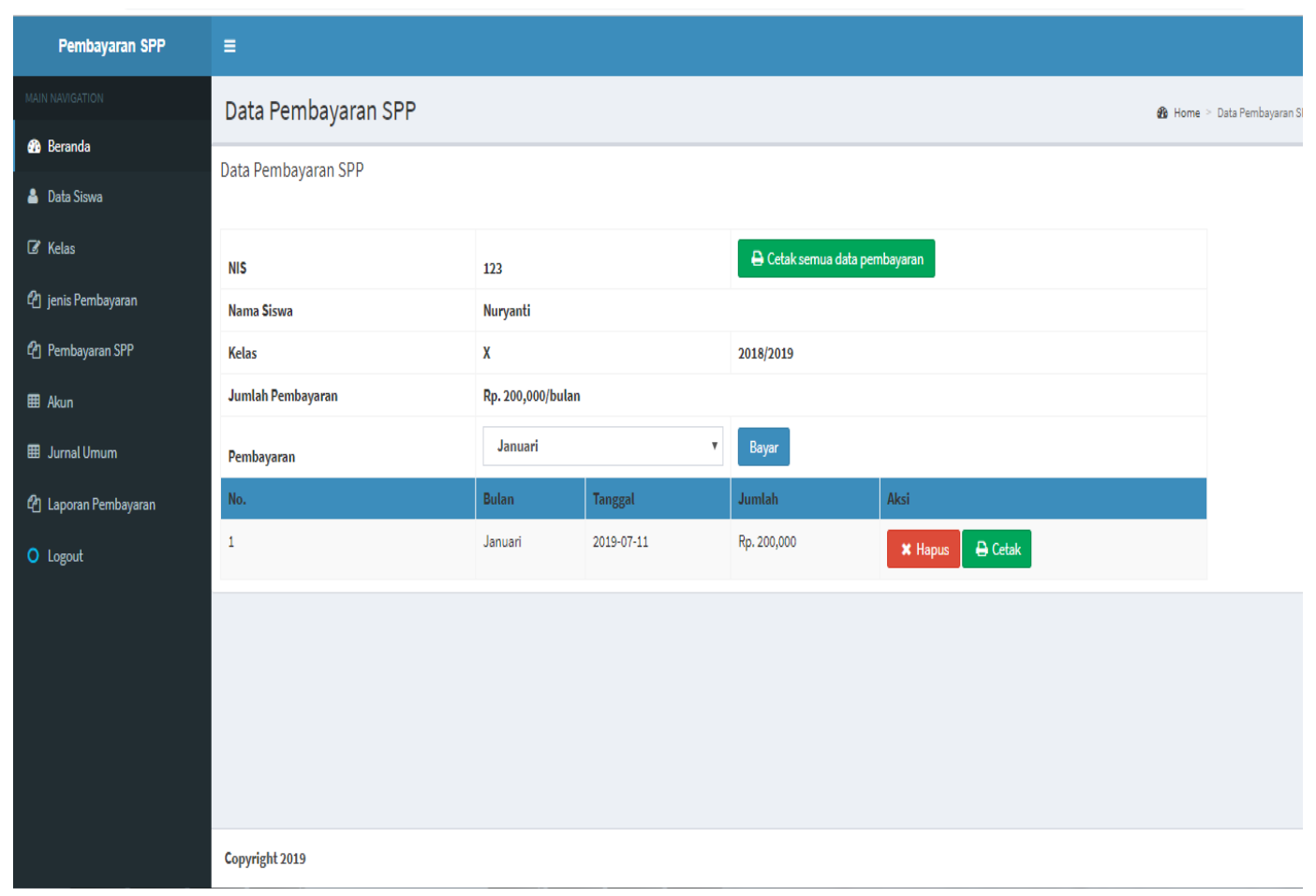

Gambar 12. Halaman Pembayaran SPP

g. Halaman Data Akun

Pada halaman data akun berfungsi sebagai data utama untuk penyimpanan data akun yang akan diperoses pada halaman jurnal umum dan berpengaruh pada halaman laporan.

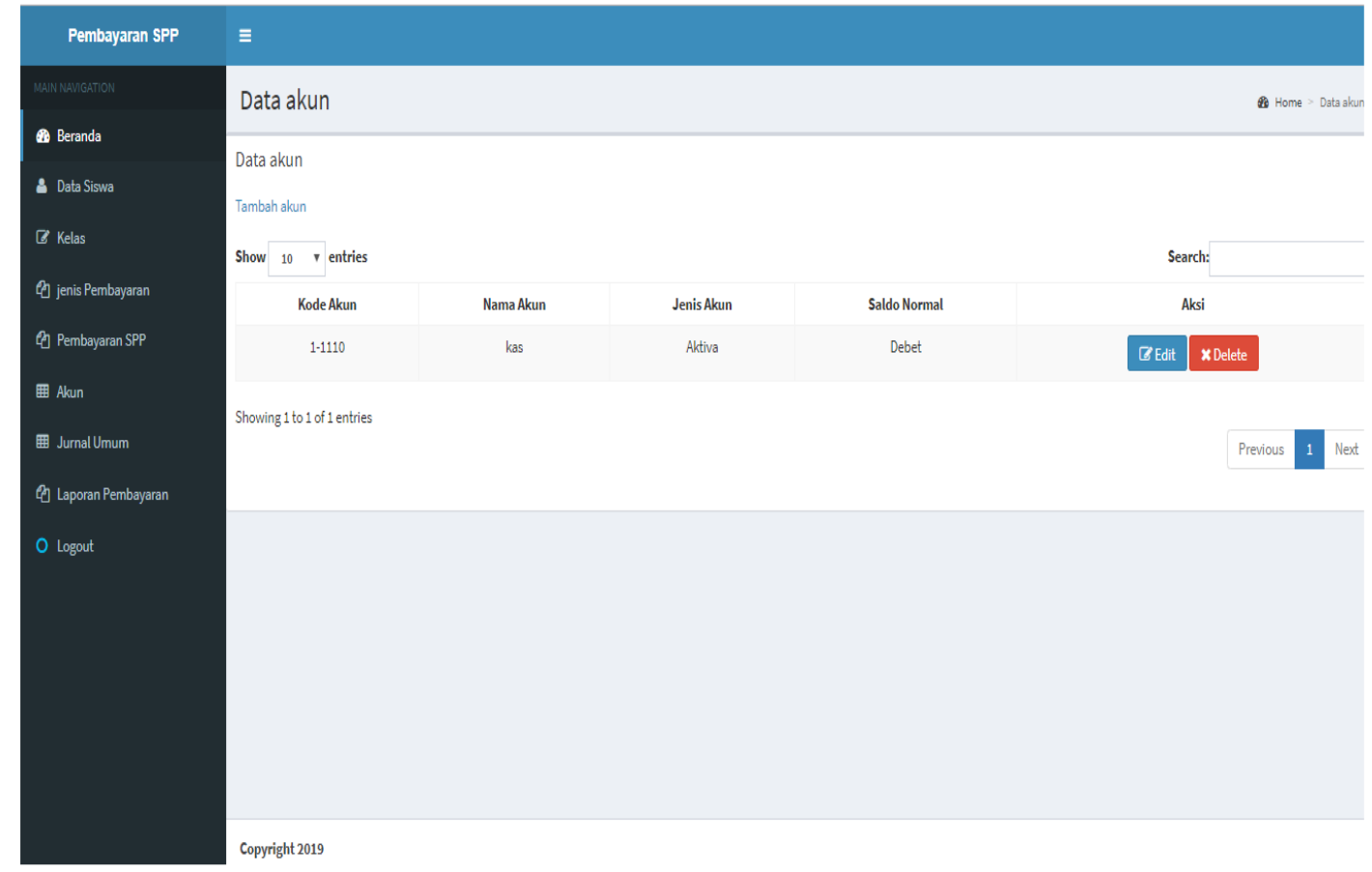

Gambar 13. Halaman Data Akun

h. Halaman Jurnal Umum 
Halaman ini akan menampilkan jurnal umum yang berhubungan dengan halaman akun dan halaman pembayaran SPP.

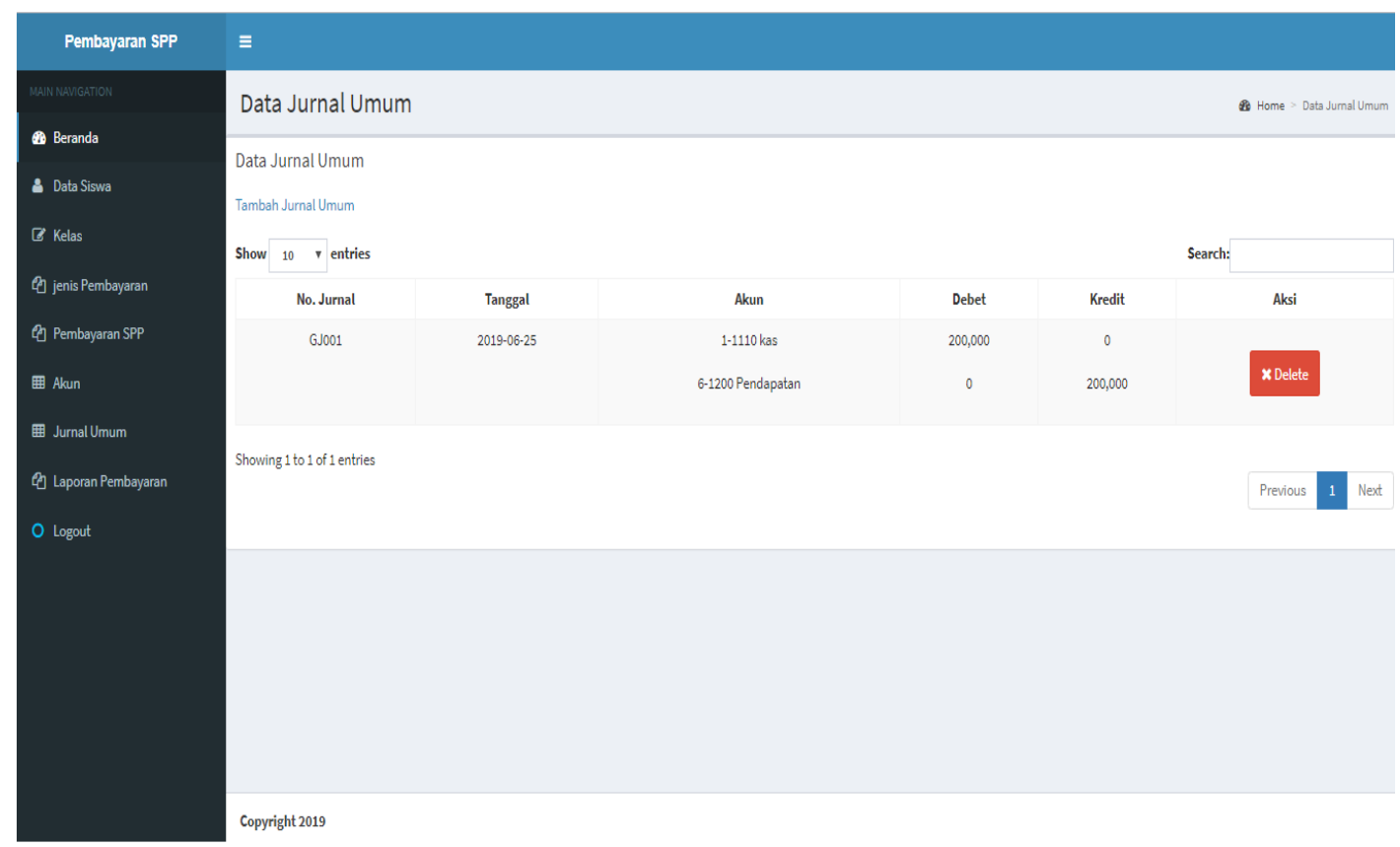

Gambar 14. Halaman Jurnal Umum

i. Halaman Laporan Pembayaran

Halaman ini akan menampilkan data laporan pembayaran yang di hasilkan dari halaman sebelumnya yaitu halaman jenis pembayaran, halaman pembayaran SPP, data akun, dan jurnal umum.

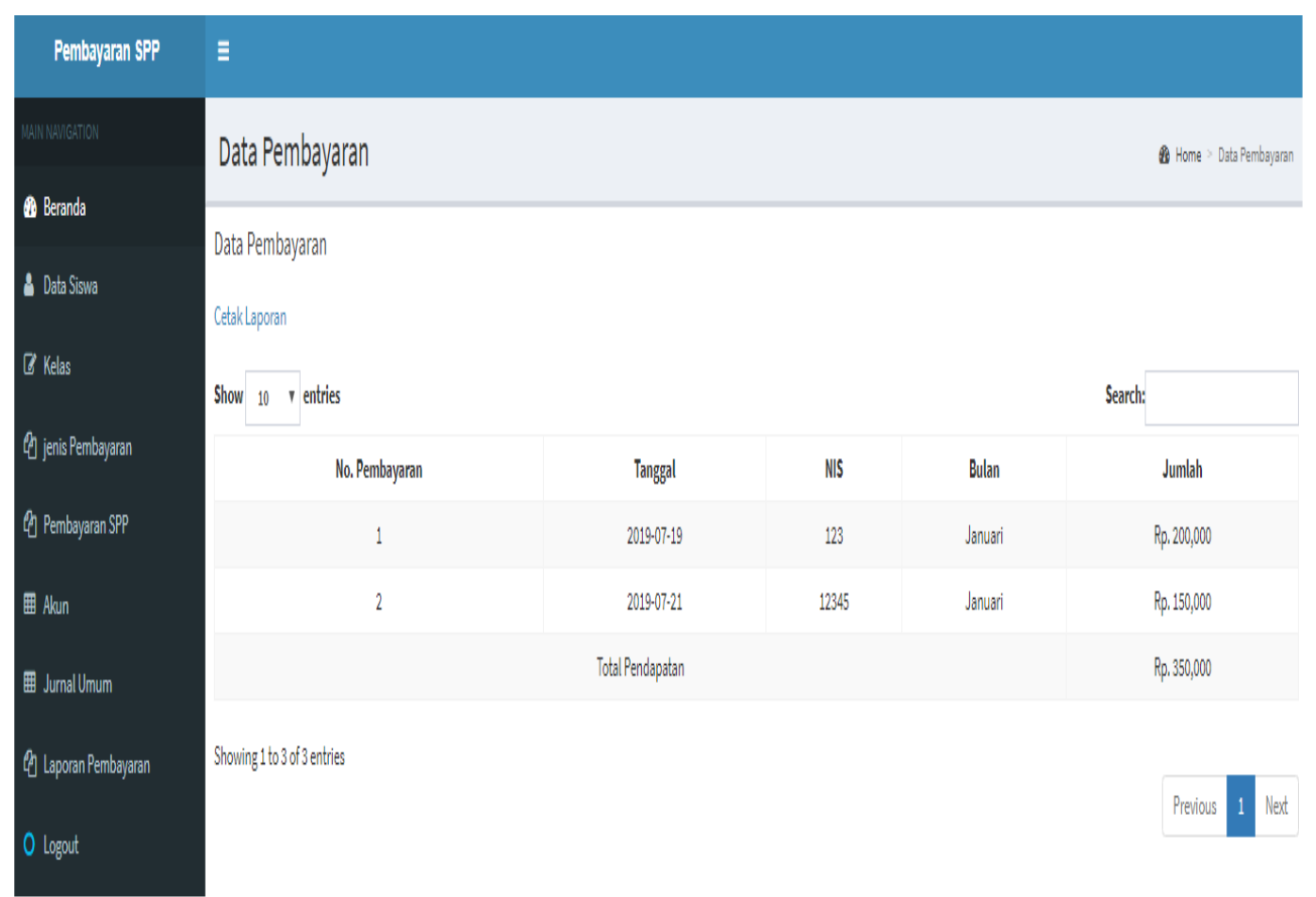

Gambar 15. Halaman Laporan Pembayaran

\subsection{Spesifikasi Hardware dan Software}


Berikut adalah spesifikasi hardware dan software yang dibutuhkan untuk aplikasi SPP:

Tabel 1. Spesifikasi Hardware dan Software Aplikasi SPP

\begin{tabular}{ll}
\hline Kebutuhan & Keterangan \\
\hline Sistem Operasi & Windows 10-Enterprise-64 bit \\
Processor & AMD-450 APU with- Redeon ${ }^{\mathrm{TM}} \mathrm{HD}$ Graphics (2 CPU-s), $\sim 1,6 \mathrm{GHz}$ \\
RAM & $4 \mathrm{~GB}$ \\
Hardisk & $320 \mathrm{~GB}$ \\
Monitor & $1366 \times 768$ pixcel \\
Browser & Google Chrome \\
Printer & Inject/Laserjet \\
\hline
\end{tabular}

\section{Kesimpulan}

Perancangan aplikasi yang dirancang pada penelitian ini ditujukan untuk proses administrasi pembayaran SPP pada Ponpes Al-Istiqomah memiliki solusi untuk mempermudah, mempercepat dan aman karena setiap data administrasi pembayaran ditangani oleh admin dengan keamanan sistem login, selain itu proses pencatatan data pembayaran SPP terhubung secara otomatis ke pembuatan laporan sehingga akan meminimalkan terjadinya kesalahan dalam proses pencatatan laporan penerimaan pembayaran SPP.

\section{Daftar Rujukan}

[1] M. Hariyanto, "Sistem Informasi Pembayaran Sumbangan Pengembangan Pendidikan (SPP) Pada SMK Periwatas Tasikmalaya," in SNIPTEK, 2015, pp. 137-140.

[2] M. Muslihudin and Helmiyanto, "Aplikasi Pembayaran SPP Berbasis Android Di Madrasah Aliyah Walisongo Lampung Tengah,” J. Sist. Inf. Manaj. Basis Data, vol. 3, no. 1, pp. 68-80, 2020.

[3] R. Taufiq, D. A. Magfiroh, D. Yusuf, and Yulianti, "Analisis dan Desain Sistem Informasi Pembayaran Sumbangan Pembinaan Pendidikan (SPP) di SMK Avicena Rajeg,” J. Teknol. Sist. Inf. dan Apl., vol. 3, no. 1, pp. 15-21, 2020.

[4] A. Rochman, A. Sidik, and N. Nazahah, "Perancangan Sistem Informasi Administrasi Pembayaran SPP Siswa Berbasis Web Di SMK Al-Amanah,” J. SISFOTEK Glob., vol. 51-56, no. 8, p. 1, 2018.

[5] D. Oscar, Y. I. Maulana, A. Haidir, and A. G. Alhaq, "Sistem Informasi SPP \& Pembayaran Sekolah Berbasis Web Pada Mts Al-Ihsan Pondok Gede Bekasi,” Indones. J. Netw. Secur., vol. 8, no. 2, pp. 1-5, 2019.

[6] G. D. Harta, I. P. Julianto, and M. A. Wahyuni, "Analisis Penerapan Sistem Pembayaran SPP Melalui Aplikasi Pembayaran SPP Terkomputerisasi Pada SMA Negeri 4 Singaraja," JIMAT (Jurnal Ilm. Mhs. Akuntansi), vol. 9, no. 3, pp. 203-215, 2018.

[7] S. Hasan and N. Muhammad, "Sistem Informasi Pembayaran Biaya Studi Berbasis Web Pada Politeknik Sains Dan Teknologi Wiratama Maluku Utara,” IJIS-Indonesian J. Inf. Syst., vol. 5, no. $1,2020$.

[8] D. S. Ramdan and S. A. B. Putra, "Perancangan Dan Implementasi Aplikasi Sistem Informasi Pengelolaan Data UKM (Unit Kegiatan Mahasiswa) Berbasis Web Di Politeknik TEDC Bandung," J. TEDC, vol. 99-103, no. 14, p. 1, 2020.

[9] I. Sutoyo, "Perancangan Sistem Informasi Pembayaran SPP Terpadu Menggunakan Model Prototipe," INTI Nusa Mandiri, vol. 14, no. 2, pp. 145-152, 2020.

[10] Y. Heriyanto and N. Oktavianis, "Perancangan Sistem Informasi Pembayaran SPP Pada SMK 
Negeri 04 Pekanbaru Berbasis Dekstop,” J. Intra-Tech, vol. 3, no. 1, pp. 10-15, 2019.

[11] F. A. Nusantara, D. D. S. Fatimah, and S. Rahayu, "Perancangan Sistem Informasi Pembayaran Sumbangan Pendidikan di Sekolah Menengah Kejuruan Darussalam Tarogong Kaler," J. Algoritma., vol. 16, no. 02, pp. 270-277, 2019.

[12] H. Santono and E. Sediyono, "Implementasi Sistem Informasi Pembayaran SPP Berbasis Web, Barcode, dan SMS Gateway," in Seminar Nasional Teknologi Informasi dan Komunikasi, 2019, pp. 255-260.

[13] S. Wahyudi, "Pengembangan Sistem Informasi Klinik Berbasis Web," Riau J. Comput. Sci., vol. 6 , no. 1 , pp. 50-58, 2020. 